Agro-Science Journal of Tropical Agriculture, Food, Environment and Extension Volume 8 Number 1 January 2009 pp. 66 - 73

ISSN1119-7455

\title{
MEAT YIELD AND THE EFFECTS OF CURING ON THE CHARACTERISTICS OF SNAIL MEAT
}

\author{
Okonkwo, T. M. and Anyaene, L. U. \\ Department of Food Science and Technology, University of Nigeria, Nsukka, Nigeria.
}

\begin{abstract}
Yield of different parts of snail (Archachatina marginata) was obtained by collecting 100 snails at random from Ibagwa-Aka in Igbo-Eze local Government Area of Enugu State and weighing each snail and its parts i.e. the shell, foot (edible portion) and offal (composed of the viscera, blood and slime) and the proximate composition of the edible portion (foot) was obtained. Thereafter, onekilogram portions of the foot were cured for $16 \mathrm{~h}$ by immersing and equilibrating (under room conditions) in one liter of solution containing $0 \%, 10 \%, 20 \%$ and $30 \%$ salt. The samples were draindried after curing and analyzed. Results show that the edible portion (foot) accounted for about $38.5 \%$ of the live weight of the snail while the inedible portion accounted for more than 60\%. While all parts increased quantitatively as the snail increased in size, the shell was accumulated more and at the expense of the foot and offal. Proximate analysis suggests that the moisture content (79.5\%) and crude protein (18.9\%) approximated those of raw beef muscle. During curing, moisture content and water activity decreased as the concentration of salt in the curing solution increased, presumably due to osmotic dehydration. Moisture content, water activity and pH reduced further during storage. However, those samples treated with $30 \%$ salt maintained lower moisture and water activity through storage compared with other samples. Peroxide value and total viable microorganisms increased in all samples during storage but salt treatment increased rancidity while inhibiting the growth of microorganisms.
\end{abstract}

Key words: Meat curing, Snail, yield, Archachatina marginata.

\section{INTRODUCTION}

Snails have a long standing importance as a source of human food and products from snail belong to foodstuff with high nutritional value (Tremlova, 2001), containing food energy, high quality proteins, vitamins and minerals. They are eaten by the rich and poor, urban and rural dwellers as well as in all continents of the world. The snail stands in the same position in the world with fin, adductor and abalone which is popular all over international markets, especially Europe and America (ZASBDC, 2008). International consumption of snail products is about 400,000 tons which is equivalent to about 2,000,000 tons of fresh snail (ZASBDC, 2008). In forest zone of West Africa, snails are known to significantly contribute to the proteins and iron contents of the diets of the rural populace (Ogbeide, 1971: Ajayi et al., 1978) and the species, Archachatina marginata, is found mainly in the forest zone of Nigeria.
In many parts of the world, considerable attention has been directed on studies relating to carcass evaluation and body composition of meat animals (Owen and Norman, 1977: Joksimovic and Ognjanovic, 1977) including snails (Ajayi, et al., 1978). This is partly for providing information necessary for a full evaluation of improvements in nutrition, general management and genetic up-grading of the meat animals under consideration and partly because the knowledge of (and information on) the size and weight of the edible portion as well as the chemical composition from a particular type of animal can greatly assist in more efficient marketing or pricing of such an animal. It is known, judging from results obtained from studies on conventional meat animals, that the proportion considered to be edible differs from one type of animal to 
Effects of Curing on Characteristics of Snail Meat

another (Valin et al., 1984: Kempster et al., 1982) and even within animal types, variation from country to country exists (Owen and Norman, 1977; Gali and Ali, 1985a,b). This is especially important, as snail farming which has gained popularity in many parts of the world may soon become fashionable in Nigeria (Okeke, 2007) partly due to the inability of the conventional livestock (cattle, sheep, goat, pig, etc.) to supply the much needed proteins to the urban and rural populace and partly due to the need to increase the variety of meat products available or to produce special delicacies from snail meat.

Although most snails are consumed near or at the place of origin/capture, there is considerable international trade in snail meat (Elmslie, 1982) as there is also a considerable demand for snail meat. This suggests that most often, snails are transported from their places of origin/capture to urban cities or other countries either alive or in semi-processed form or readyto-eat conditions (ZASBDC, 2008). Also, in the homes, there could be some delays between the time of extraction and consumption of the snail meat. This means that some form of preservation is necessary as once extracted, the raw snail meat, similar to beef, is highly perishable as a result of changes caused by contaminating microorganisms, enzymes naturally present in the meat, insects, chemical and physical processes. If these deteriorative processes are not controlled or prevented, they would soon make the snail meat unfit for consumption.

Common salt (sodium chloride) has been used for centuries to delay meat spoilage and it acts by dehydrating the meat and/or reducing the water activity of the meat to a point that it inhibits microbial growth and subsequent spoilage (Kramlich et al., 1980) The present study examines meat yield data and the effects of sodium chloride on the organoleptic qualities and shelf-life of snail meat.

\section{MATERIALS AND METHODS}

\section{Sample Collection, Processing and Yield Measurement}

The giant African snail, Archachatina marginata, used in this study was collected from Ibagwa-aka in Nsukka L. G. A. of Enugu State, Nigeria. Each of the one hundred (100) snails of varying sizes collected at random was weighed. The snail was then killed and separated into the shell, foot (edible portion) and offal (composed of the viscera, slime, blood and eggs). The shell was rinsed free of blood and slime, allowed to drain dry and thereafter weighed. The foot was washed with potassium alum
$\left(\mathrm{K}_{2} \mathrm{SO}_{4} \mathrm{Al}_{2}\left[\mathrm{SO}_{4}\right]_{3} .24 \mathrm{H}_{2} \mathrm{O}\right)$ to remove slime and blood, then rinsed with distilled water, mopped free of excess water and weighed. The weight of the offal was obtained by difference. The washed snail meat was divided into four (4) portions of one kilogram each to correspond to four curing solutions of one liter each containing $30 \%, 20 \%$, $10 \%$ and $0 \%$ salt solution. The soaked samples were allowed to equilibrate in the brine for 16 hours at ambient conditions after which the solutions were drained off and sub-samples removed from each treatment for initial analysis. The remaining portions were stored in plastic containers at room conditions for 30 hours and analyzed at intervals of three (3) hours.

\section{Analytical Methods \\ duplicate. \\ All analyses were performed in}

Proximate composition (moisture, total nitrogen, fat and ash contents), peroxide value and total viable count were determined according to the methods of AOAC (1995).

Water activity was determined on tengram sample using water activity meter $\left(\mathrm{a}_{\mathrm{W}^{-}}\right.$ analyser model 5803 of G.Lufft Mes-Und Regeltechnik, Germany) and $\mathrm{pH}$ was determined on dispersion of five-gram sample in $50 \mathrm{ml}$ of distilled water using a combined electrode.

Sensory evaluation was carried out using a thirty-man panel of judges and a 7-point Hedonic scale of one(1) disliked very much to seven (7) liked very much.

\section{Statistical Analysis}

Analysis of Variance was carried out using Completely Randomized Design according to the methods of Gomez and Gomez (1984).When significance was detected, Fisher's Least Significant Difference was used to separate means. Also, correlation analysis (when necessary) was carried out according to methods of Gomez and Gomez (1984).

\section{RESULTS AND DISCUSSION \\ Yield of Different Parts of the Snail}

Results show the mean weight of the snail to be about $83.7 \pm 3.6 \mathrm{~g}$. This is composed of $31.6 \pm 3.0 \mathrm{~g}$ (or $38.4 \pm 0.46 \%$ ) edible portion (foot), $33.6 \pm 1.6 \mathrm{~g}$ (or $40.6 \pm 0.78 \%$ ) offal and $18.6 \pm 1.2 \mathrm{~g}$ (or $20.9 \pm 0.8 \%$ ) shell. Therefore, the inedible portion (shell + offal) accounts for over $60 \%$ of the live weight of the snail while the edible portion accounts for less than $40 \%$ of the snail's live weight. This finding agrees with the results of Ajayi et al. (1978). 
Okonkwo, T. M. and Anyaene, L. U.

It is seen from Fig. 1 that there is a linear relationship between the live weight and the weight of the edible portion, offal and shell of the snail. As the snail increases in size, the edible portion, shell and offal increase quantitatively such that larger sized snails contain larger amounts of edible portion, offal and shell. However, when the edible portion is expressed as a percentage of the live weight (Fig. 2) it is found out that large sized snails contain proportionately less edible portion and offal compared to small sized snail. In contrast to the observation on edible portion and offal, it is seen that heavier snails possess proportionately heavier shells than snails with smaller body weights. It is presumed that the continuous accumulation of shell is connected with the attempt by the snail to ensure greater protection of itself from predators and other hazards. Therefore, the shell which is presumed to be the first major line of defense is continually accumulated and in order to reduce 'excess load', less internal contents (foot and offal) are elaborated as the snail grows older and/or becomes heavier.

\section{Proximate composition of Samples:}

The proximate composition of the edible portion of the snail (Table 1) shows its moisture content $(79.5 \%)$ and crude protein (16.8\%) to compare favourably with data of Okonkwo et al (1992) for raw beef. However, the fat content is low and advantageous to consumers as the association of high fat consumption with atherosclerosis and coronary heart disease is well known (Ononogbu, 1992). The ash content of about $3 \%$ is high compared to that of raw beef but it is also known that the nutritional quality of snail mineral is high especially with respect to its high iron content. The $\mathrm{pH}$ of 7.4 is due to the basicity of the potassium alum used in washing the foot and may tend to suggest less bacteriological stability during prolonged handling as it is known that meat with high ultimate $\mathrm{pH}$ spoils bacteriologically faster than meat with lower ultimate $\mathrm{pH}$ (Forrest et al., 1975; Okonkwo and Obanu, 1986). However, the lack of protection from bacterial spoilage caused by high $\mathrm{pH}$ is counter balanced by low water activity of the snail meat. The peroxide value of 0.11 (M.eq/Kg sample) suggests absence of lipid oxidation during washing of the snail meat with alum. Table 1 also summarizes the characteristics of the cured products. It is seen that equilibration in salt caused the expected reduction in moisture content probably due to osmotic dehydration. The uncured sample (control) possessed the highest moisture content while samples cured with $30 \%$ salt solution had the lowest moisture. It is likely that through water binding and reduction in moisture content, salt reduces water activity. Thus, in contrast to moisture content, the higher the salt content, the lower the water activity. Salt appeared to reduce total nitrogen presumably through solubilization of salt-soluble nitrogenous substances. Salt also appears to promote lipid oxidation and loss of fat in the samples. This is reflected in the reducing fat content and increasing peroxide value as concentration of salt increased. The mineral content increased as salt concentration increased presumably due to absorption of sodium chloride by the snail meat.

Table 1: - Characteristics of the snail meat samples after washing*

\begin{tabular}{lrrrr}
\hline \multirow{4}{*}{ Property } & \multicolumn{4}{c}{ Curing solutions } \\
\cline { 2 - 5 } & \multicolumn{1}{c}{ S\% } & \multicolumn{1}{c}{$\mathbf{1 0 \%}$} & \multicolumn{1}{c}{$\mathbf{2 0 \%}$} & \multicolumn{1}{c}{$\mathbf{3 0 \%}$} \\
& \multicolumn{1}{c}{ Salt } & \multicolumn{1}{c}{ salt } & \multicolumn{1}{c}{ salt } \\
\hline Moisture content (\%) & $79.48 \pm 2.50$ & $79.16 \pm 3.70$ & $74.64 \pm 3.40$ & $73.71 \pm 2.60$ \\
Water activity & $0.97 \pm 0.01$ & $0.95 \pm 0.01$ & $0.94 \pm 0.02$ & $0.91 \pm 0.01$ \\
Crude protein (\%) & $16.82 \pm 0.81$ & $16.24 \pm 0.42$ & $16.13 \pm 0.31$ & $14.43 \pm 0.66$ \\
Fat content (\%) & $0.70 \pm 0.11$ & $0.60 \pm 0.13$ & $0.43 \pm 0.12$ & $0.46 \pm 0.13$ \\
Ash content (\%) & $3.00 \pm 0.14$ & $3.80 \pm 0.08$ & $8.5 \pm 0.13$ & $10.90 \pm 0.14$ \\
pH & $7.40 \pm 0.05$ & $7.81 \pm 0.02$ & $8.12 \pm 0.57$ & $7.66 \pm 0.03$ \\
Peroxide value(M.eq/ & $0.10 \pm 0.01$ & $0.12 \pm 0.03$ & $0.13 \pm 0.01$ & $0.16 \pm 0.02$ \\
Kg sample) & & & & \\
Total viable count & $<10$ & $<10$ & $<10$ & $<10$ \\
(cfu/g) & & & & \\
Colour preference & $5.15 \pm 1.89$ & $5.07 \pm 1.61$ & $5.40 \pm 0.95$ & $4.93 \pm 1.48$ \\
odour preference & $4.27 \pm 0.93$ & $4.33 \pm 1.35$ & $4.97 \pm 0.81$ & $5.13 \pm 1.54$ \\
Texture preference & $4.67 \pm 1.19$ & $4.40 \pm 1.31$ & $4.73 \pm 1.34$ & $4.93 \pm 1.34$ \\
& & & \\
General acceptability & $4.73 \pm 1.24$ & $4.80 \pm 1.56$ & $4.60 \pm 0.95$ & $4.40 \pm 1.25$ \\
\hline * Values are in mean \pm standard deviation &
\end{tabular}

Table 2:- Changes in moisture content of snail meat samples during storage at ambient conditions storage (values in \%)*

\begin{tabular}{lcccc}
\hline $\begin{array}{l}\text { Storage period } \\
\text { (Hours) }\end{array}$ & \multicolumn{4}{c}{ Curing solutions } \\
& $0 \%$ & $10 \%$ & $20 \%$ & $30 \%$ \\
& salt & Salt & Salt & salt \\
\cline { 2 - 5 } & $79.48 \pm 2.5$ & $79.16 \pm 3.7$ & $74.64 \pm 3.4$ & $73.71 \pm 2.6$ \\
0 & $76.90 \pm 3.1$ & $79.00 \pm 3.2$ & $73.50 \pm 5.0$ & $70.10 \pm 4.3$ \\
3 & $76.80 \pm 4.0$ & $79.50 \pm 4.6$ & $73.80 \pm 3.9$ & $69.40 \pm 4.7$ \\
6 & $75.90 \pm 5.0$ & $78.40 \pm 4.6$ & $68.40 \pm 4.3$ & $69.90 \pm 5.3$ \\
8 & $74.80 \pm 2.8$ & $69.80 \pm 3.4$ & $67.70 \pm 3.0$ & $68.90 \pm 3.1$ \\
24 & - & $74.60 \pm 6.2$ & $64.90 \pm 5.4$ & $64.20 \pm 5.8$ \\
\hline
\end{tabular}

$*$ Values are in mean \pm standard deviation 

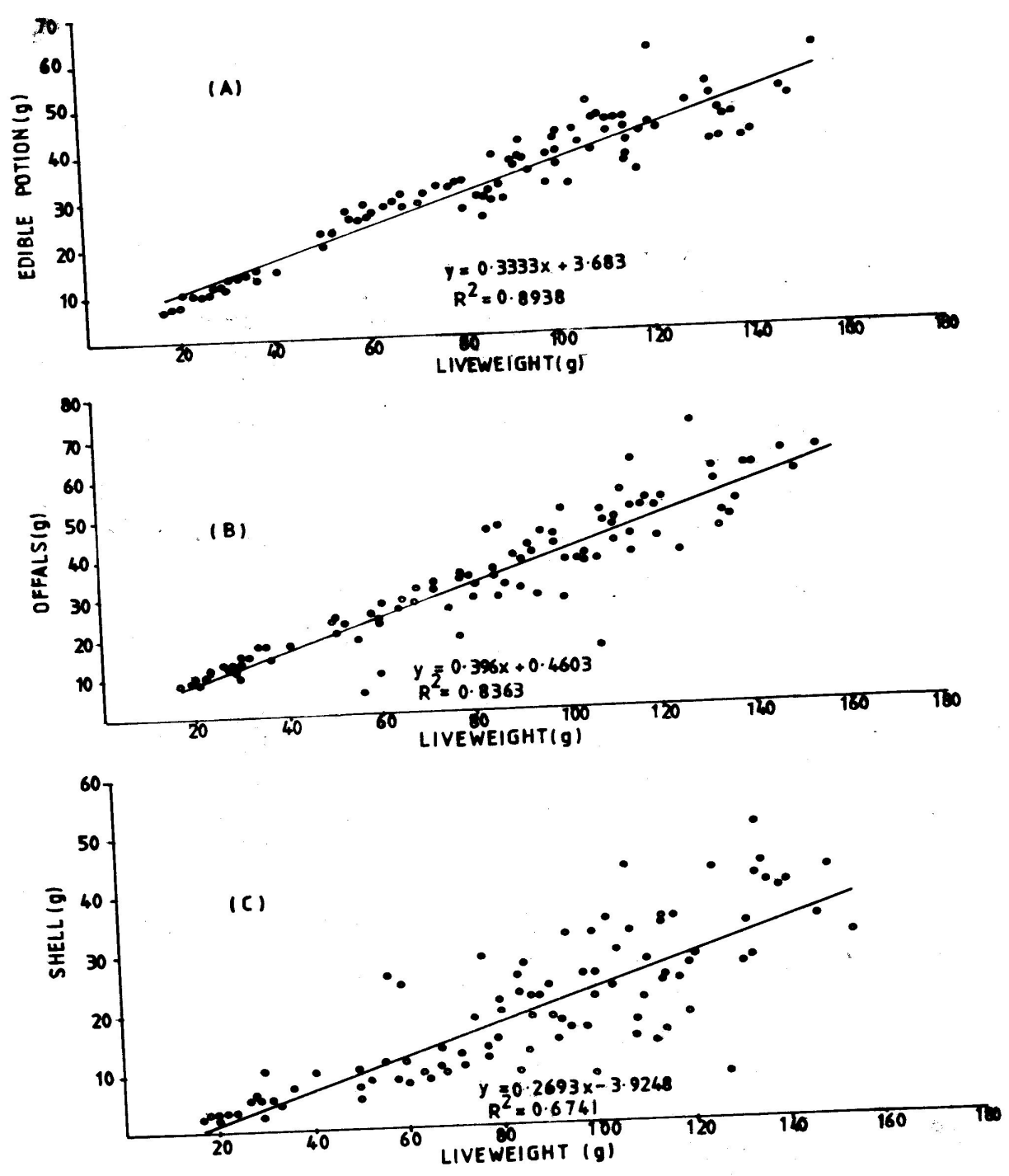

Fig. 1: DE PENDENCE OF (A) EDIBLE POTION, (B) OFFALS AND(C) SHELL ON LIVE WEIGHT ON SNAIL. 
Okonkwo, T. M. and Anyaene, L. U.
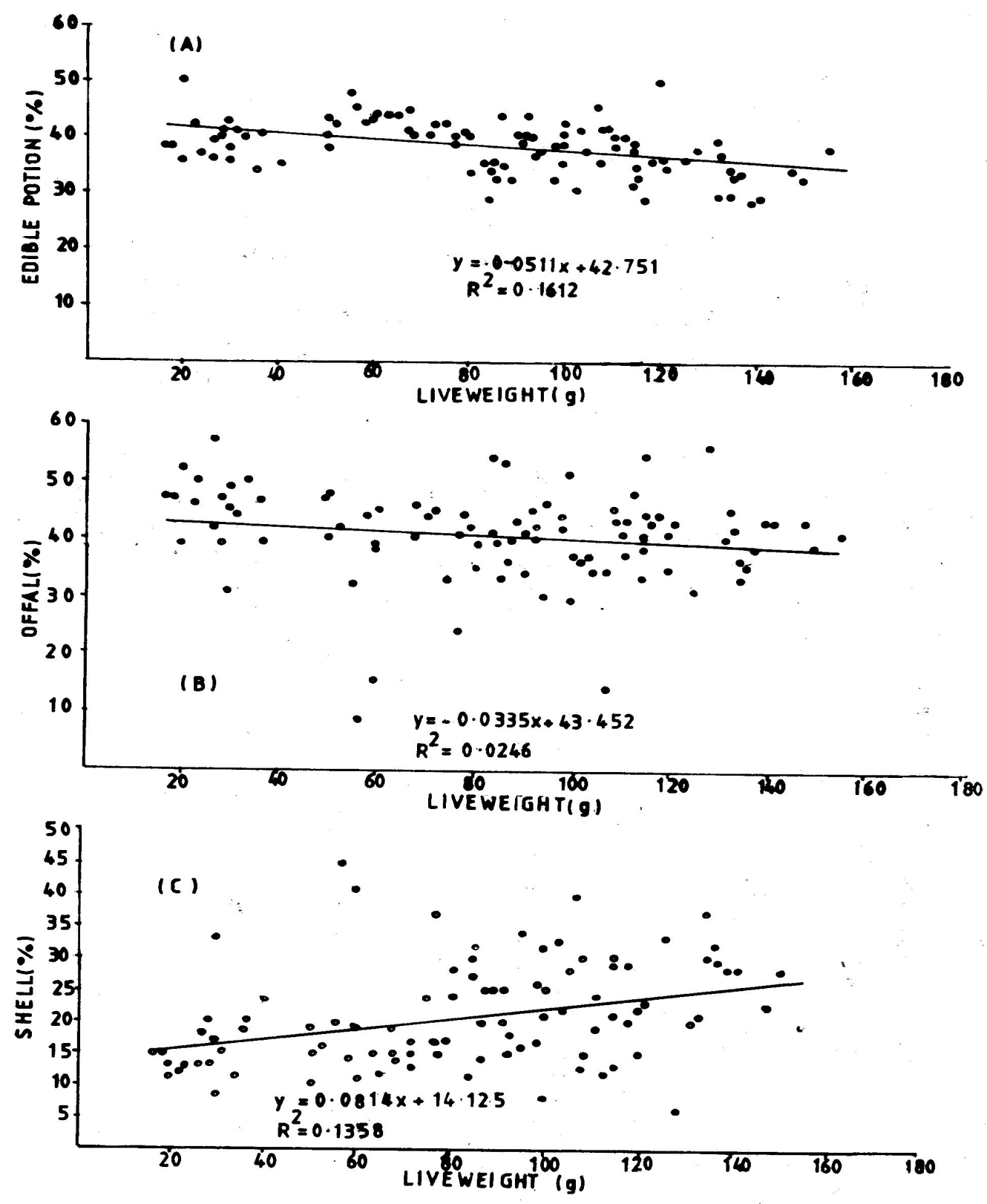

Frg. 2 : RELATIONSHIP OF (A) EDIBLE PORTION(B) OFFALS AND (C). SHELL TO LIVE WEIGHT OF SNAIL. 
Effects of Curing on Characteristics of Snail Meat

\section{Changes During Storage:}

Since objectionable spoilage characteristics were observed in the uncured samples at about 24 hours of storage, further storage and analysis of the uncured samples were discontinued after the $24^{\text {th }}$ hour of storage.

The changes in moisture content during storage are shown in Table 2. All samples significantly $(\mathrm{p}<0.05)$ reduced in moisture content during storage. For example, the moisture content of the sample cured in $30 \%$ salt solution reduced from $73.71 \pm 2.6 \%$ at the start of storage to $64.20 \pm 5.8 \%$ at the end $\left(30^{\text {th }}\right.$ hour) of storage. Similar trends were observed for samples cured in $0 \%, 10 \%$ and $20 \%$ salt solutions. The water activity also expectedly reduced. Moisture content has significant $(\mathrm{p}<0.05)]$ correlation $(\mathrm{r}=0.81)$ with water activity. The reduction of moisture during storage is explained by the ability of the penetrating salt (through osmotic dehydration) to denature the muscle proteins and consequently reduce their water holding capacity (Weierbicki et al., 1957). Therefore, those samples which were equilibrated in solutions of higher salt content and which presumably absorbed higher quantity of salt expectedly had lower moisture content through storage. The reducing moisture and water activity would suggest increasing microbiological safety and stability especially through inhibition of bacterial organisms. However, it is expected that the more osmophilic/halophilic bacteria and fungi can, within this range, adapt and cause spoilage of the products.

Table 3:- Changes in $\mathrm{pH}$ of snail meat samples during storage at ambient conditions*

\begin{tabular}{lcccc}
\hline $\begin{array}{l}\text { Storage } \\
\begin{array}{l}\text { Period } \\
\text { (Hours) }\end{array}\end{array}$ & \multicolumn{4}{c}{ Curing solutions } \\
\cline { 2 - 5 } & $\begin{array}{c}0 \% \\
\text { salt }\end{array}$ & $\begin{array}{c}10 \% \\
\text { salt }\end{array}$ & $\begin{array}{c}20 \% \\
\text { salt }\end{array}$ & $\begin{array}{c}30 \% \\
\text { salt }\end{array}$ \\
\hline 0 & $7.40 \pm 0.05$ & $7.81 \pm 0.02$ & $8.12 \pm 0.05$ & $7.66 \pm 0.03$ \\
3 & $6.60 \pm 0.01$ & $7.62 \pm 0.09$ & $7.59 \pm 0.10$ & $7.35 \pm 0.11$ \\
6 & $6.40 \pm 0.03$ & $7.09 \pm 0.07$ & $8.09 \pm 0.11$ & $7.40 \pm 0.04$ \\
18 & $6.10 \pm 0.06$ & $5.74 \pm 0.06$ & $7.44 \pm 0.05$ & $8.10 \pm 0.09$ \\
24 & $6.04 \pm 0.02$ & $5.40 \pm 0.04$ & $7.62 \pm 0.03$ & $7.75 \pm 0.05$ \\
30 & - & $5.08 \pm 0.01$ & $6.24 \pm 0.08$ & $6.48 \pm 0.02$ \\
\hline
\end{tabular}

* Values are in mean \pm standard deviation
Table 4:- Changes in peroxide value of snail meat samples during storage at ambient conditions (M.eq/Kg sample)*

\begin{tabular}{lcccc}
\hline $\begin{array}{l}\text { Storage } \\
\text { Period } \\
\text { (Hours) }\end{array}$ & \multicolumn{4}{c}{ Curing solutions } \\
\cline { 2 - 5 } & $0 \%$ & $10 \%$ & $20 \%$ & $30 \%$ \\
salt & Salt & salt & salt \\
0 & $0.11 \pm 0.0$ & $0.12 \pm 0.03$ & $0.13 \pm 0.01$ & $0.16 \pm 0.02$ \\
3 & $0.20 \pm 0.03$ & $0.26 \pm 0.02$ & $0.39 \pm 0.01$ & $0.40 \pm 0.04$ \\
6 & $0.37 \pm 0.05$ & $0.38 \pm 0.01$ & $0.49 \pm 0.03$ & $0.54 \pm 0.06$ \\
18 & $0.64 \pm 0.05$ & $0.65 \pm 0.03$ & $0.66 \pm 0.07$ & $0.68 \pm 0.04$ \\
24 & $0.90 \pm 0.02$ & $0.94 \pm 0.01$ & $0.89 \pm 0.09$ & $1.48 \pm 0.08$ \\
30 & - & $1.10 \pm 0.14$ & $1.12 \pm 0.06$ & $2.00 \pm 0.10$ \\
\hline * Values are in mean \pm standard deviation
\end{tabular}

Table 5:- Changes in total viable microorganisms of snail meat samples during storage at ambient conditions (cfu/g)

\begin{tabular}{lcclc}
\hline $\begin{array}{l}\text { Storage } \\
\text { period }\end{array}$ & \multicolumn{5}{c}{ Curing solutions } \\
(Hours) & $\begin{array}{l}0 \% \\
\text { Salt }\end{array}$ & $10 \%$ Salt & $20 \%$ Salt & $30 \%$ Salt \\
& - & & - & - \\
3 & $2.5 \times 10^{2}$ & - & - & - \\
6 & $2.7 \times 10^{2}$ & $2.8 \times 10^{2}$ & $3.0 \times 10^{2}$ & -- \\
18 & $3.1 \times 10^{3}$ & $3.5 \times 10^{2}$ & $3.2 \times 10^{2}$ & $2.5 \times 10^{2}$ \\
24 & $3.9 \times 10^{3}$ & $2.9 \times 10^{2}$ & $4.1 \times 10^{2}$ & $3.8 \times 10^{2}$ \\
30 & - & $3.0 \times 10^{3}$ & $3.1 \times 10^{3}$ & $3.0 \times 10^{3}$ \\
\hline
\end{tabular}

Table 6:- Sensory evaluation of cured snail meat samples during storage at

\begin{tabular}{lcllll}
\hline $\begin{array}{l}\text { Curing } \\
\text { solution }\end{array}$ & $\begin{array}{l}\text { Storage } \\
\text { period } \\
\text { (hours) }\end{array}$ & $\begin{array}{l}\text { Colour } \\
\text { reference }\end{array}$ & $\begin{array}{l}\text { Odour } \\
\text { preference }\end{array}$ & $\begin{array}{l}\text { Texture } \\
\text { preference }\end{array}$ & $\begin{array}{l}\text { General } \\
\text { acceptability }\end{array}$ \\
\hline $0 \%$ salt & 0 & $5.13 \pm 1.89$ & $4.27 \pm 0.93$ & $4.67 \pm 1.19$ & $4.73 \pm 1.24$ \\
& 18 & $4.93 \pm 1.39$ & $3.40 \pm 1.70$ & $4.40 \pm 1.58$ & $4.20 \pm 1.90$ \\
$10 \%$ salt & 0 & $5.07 \pm 1.61$ & $4.33 \pm 1.35$ & $4.40 \pm 1.31$ & $4.80 \pm 1.56$ \\
& 18 & $4.93 \pm 1.77$ & $4.47 \pm 0.96$ & $4.33 \pm 1.35$ & $5.00 \pm 1.15$ \\
$20 \%$ salt & 0 & $5.40 \pm 0.95$ & $4.97 \pm 0.81$ & $4.73 \pm 1.34$ & $4.60 \pm 0.95$ \\
& 18 & $3.33 \pm 1.14$ & $4.47 \pm 0.88$ & $4.93 \pm 1.39$ & $4.40 \pm 1.25$ \\
$30 \%$ salt & 0 & $4.93 \pm 1.48$ & $5.13 \pm 1.54$ & $4.93 \pm 1.34$ & $4.40 \pm 1.25$ \\
& 18 & $3.93 \pm 1.12$ & $4.47 \pm 0.81$ & $5.00 \pm 0.73$ & $4.40 \pm 1.20$ \\
\hline
\end{tabular}

*Values are in mean \pm standard deviation 
Okonkwo, T. M. and Anyaene, L. U.

Table 3 shows that the $\mathrm{pH}$ of all samples reduced during storage. For example, the $\mathrm{pH}$ of the sample cured in $10 \%$ salt solution reduced from $7.81 \pm 0.02$ at the beginning of storage to about $5.08 \pm 0.01$ at the end $\left(30^{\text {th }}\right.$ hour $)$ of storage. This trend is similar to that of other samples treated with $0 \%, 20 \%$ and $30 \%$ salt solutions. Similar results have been observed in intermediate moisture meats and have been attributed to the protein crosslinking reactions which appear to remove amino groups from the system and consequently depress $\mathrm{pH}$ (Webster et al., 1982; Okonkwo et al., 1992b). Although no particular trend could be established in the initial $3 \mathrm{~h}$ of storage but thereafter, samples equilibrated in solutions of higher salt concentrations maintained higher compared to those equilibrated in solutions of lower salt concentrations. Thus, addition of salt appears to cause a buffering effect and the higher the salt content, the greater this resistance to $\mathrm{pH}$ change.

The extent of rancidity or lipid oxidation as shown by peroxide value is shown in Table 5. Although generally very low, $(0.13 \pm 0.02 \mathrm{M}$.eq. $/ \mathrm{Kg}$ sample at the beginning of storage) all samples increased in peroxide value due to lipid oxidation and hydrolysis. It can be observed from Table 5 that samples equilibrated in solution of $30 \%$ salt had the highest peroxide value through storage supporting the view that salt is a prooxidant (Forrest et al., 1975; Neer and Mandigo, 1977). Samples treated without salt also gave values for lipid oxidation suggesting that microbial hydrolysis of lipids was also taking place as it is shown that in Table 6 uncured samples supported highest microbial proliferation.

Changes in total viable microorganisms are shown in Table 6. There were no growths of microorganisms in all samples soon after equilibration. Thereafter, microbial growth started in all samples although the time of onset and extent of growth varied with different treatments. Thus, while growth started in the uncured samples from the $3^{\text {rd }}$ hour of storage, cell multiplication was observed from the $18^{\text {th }}$ hour on samples equilibrated in $30 \%$ salt solution. This suggests that by prolonging the lag phase and retarding cell multiplication, salt delays rate and extent of microbial spoilage of snail meat and thereby prolongs the shelflife of the cured products.

Table 6 shows the summary of the changes in sensory characteristics of the cured snail meat products. Results show that there were slight reductions in the desirable sensory characteristics of the snail meat during ambient storage but these reduct ions were not significant $(\mathrm{p}>0.05)$ within the first 18 hours of storage. No significant differences $(p>0.05)$ could be found between treatment except that objectionable odour was beginning to be evident in the uncured samples by the $18^{\text {th }}$ hour of storage.

\section{CONCLUSION}

This study has shown the meat yield of snail to be less than $40 \%$ by weight and that internal contents of the snail are elaborated less than the shell as the snail grows older or heavier. Also this study has demonstrated that the shelf-life of raw snail meat can be extended by curing with common salt (sodium chloride). The sensory evaluation has shown that the organoleptic characteristics of the snail meat were not appreciably lowered during curing with salt and storage of the cured products However, during prolonged storage at ambient conditions (i.e. up to 30 hours) the shelf-life and acceptability of the snail meat cured with salt alone may depend on the balance of the effects of water activity and salt content on one hand with lipid oxidation on the other hand. This is because while salt, through lowering of water activity can inhibit or delay microbial growth and spoilage, it can, through promoting lipid oxidation, cause off-flavour (rancidity). Depending on the extent, both can result to unacceptability of the meat and therefore justifies the need to add antioxidant to the curing mixture.

\section{REFERENCES}

Ajayi, S. S., Moriaty, C. and Aweri, M. D. (1978). Some observations on the biology and nutritive value of the West African giant land snail Archchatina marginata. East African Wild life Journal 16: 85-95

AOAC (1995) Official methods of analysis. $15^{\text {th }}$ edition. Association of Official Analytical Chemists. Washington D. C.

Emlslie, L. J. (1982). The potential for snail farming. Span 25: 35-37.

Forrest, J. C., Aberle, E. D., Hedrick, H. B., Judge, M. D. and Merkel, R. A. (1975) Principles of meat science. $1^{\text {st }}$ edition. W. H. Freeman and Co. San Franscico.

Gali, E. S.and Ali, A. E. (1985a). Meat from Sudan desert sheep and goats. Part1: Carcass yield, offal and distribution of carcass tissues. Meat Science 13: 217-228.

Gali, E. S. and Ali, A. E. (1985b). Meat from Sudan desert sheep and goats. Part 2: Composition of muscular and fatty tissues. Meat Science 13: 229-236.

Gomez, A. A. and Gomez, A. H. (1984). Statistical procedures for agricultural research. Second edition. A Wiley and Sons Publishers. New York

Joksimovic, J. and Ognjanovic, A (1977). Comparism of carcass yield, carcass composition and quality characteristics of buffalo meat and beef. Meat Science 1: 105-110.

Kempster, A. J., Cuttbertson, A. and Harrington, C. (1982). The relationship between conformation and the yield and distribution of lean meat in the carcasses of British pigs, cattle and sheep: A critical review. Meat Science 6: 37-54. 
Effects of Curing on Characteristics of Snail Meat

Kramlich, W. E., Pearson, A. M. and Tauber, F. W. (1980). Processed meats. The AVI Publishing Company, Inc. Westport, Connecticut.

Lawrie, R. A. (1991) Meat science. $5^{\text {th }}$ edition. Pergammon Press, London.

Neer, K. L. and Mandigo, R. W. (1977). Effect of salt, sodium tripolyphosphate and frozen storage time on the properties of flaked cured pork product. Journal of Food science. 42: 738742.

Ogbeide, O. (1971). Nutritional hazards of the taboos and preferences in Mid-Western Nigeria. American J. Clinical Nutrition 27: 213-216.

Okeke, G. C. [2007]. The potentials for snail farming in Nigeria. Personal communication

Okonkwo, T. M., Obanu, Z. A. and Ledward, D. A. (1992a). Characteristics of some intermediate moisture smoked meats. Meat Science 31: 135-145.

Okonkwo, T. M., Obanu, Z. A (1992b). The stability of some intermediate moisture smoked meat during storage at $30^{\circ} \mathrm{C}$ and $38^{\circ} \mathrm{C}$. Meat Science 31: 245-255.

Ononogbu, I. C. [1992]. I am a child of tomorrow. Lipid Awareness Enteprises Publications. number 92-01.
Owen, J. F. and Norman, G. A. (1977). Studies on the meat production characteristics of Bostwana goats and sheep - Part II. General body composition, carcass measurements and joint composition. Meat Science 1: 283-306.

Tremlova, B. [2001]. Histological examination of snail meat specialities. Fleischwirtschaft, 81(12): 96-97.

Valin, C., Pinkas, A., Dragner, H., Biokovski, S. and Polikronov, D. (1994). Comparative study of buffalo meat and beef. Meat Science 10: 6984.

Webster, C.E.M., Ledward, D. A. and Lawrie, R, A. (1982). Effect of oxygen and storage temperature on intermediate moisture meat products. Meat Science 6: 111-121.

Weirbicki, E., Cahill, V. R. and Deatherage, F. E. (1957). Effect of added sodium chloride, potassium chloride, calcium chloride, magnesium chloride and citric acid on meat shrinkages at $70^{\circ} \mathrm{C}$ and of added sodium chloride on drip losses after freezing and thawing. Food Technology, 11: 74-76.

ZASBDC. (2008). Canned snail meat - China canned food, seafood, meat in canned food. Zhejiang Aotuokang Special Biology Development Centre [ZASBDC], China. 